\title{
Application of Ferris Wheel Concept on Vertical Transportation System
}

\author{
KingChun TSANG \\ School of Architecture \\ South China University of Technology \\ GuangZhou, 510640, China
}

\begin{abstract}
This study is to find out the possibility of applying the Ferris Wheel concept to vertical transportation system (VTS). Although the engineers have considered different types of VTS and trying to maximum the efficiency, for example, Double Deck Elevator, Miconic 10 elevator system by Schindler, high speed elevator, etc. But do these methods can really help?The case study exactly point out the problem. Although there are 8 passenger elevators, efficiency of VTS is very low, passenger use almost one minute for waiting the elevator. Therefore, this study not only tries to find out the possibility of applying the Ferris Wheel concept in VTS, but also try to give a solution for the problem. Some VTS working principles are also introduced here as they can be applied to the proposed system. Actually, not only VTS, system such as railway, roller coaster, their working principle are also similar to the proposed system, but $I$ have not discussed about them in this report in order to restrict the volume to the specified limit. As I have just brought out the idea, I really welcome others doing further development in this topic, and I believe that the proposed system can really help the traditional VTS of the building.
\end{abstract}

Keywords- ferris wheel, vertical transportation system, paternoster elevator

\section{INTRODUCTION}

The role of Vertical Transportation System (VTS) in building becomes more and more important since the appearance of high-rise buildings in the late $19^{\text {th }}$ century. However, most of the VTS in high-rise buildings are group together in every floor in order to maximum the efficiency. However, architects want to design a building in the least restricted way, and those lift shafts may become one of their limitations.

Moreover, speed and capacity are both the main issue that passengers want to improve and care about when traveling. Therefore, the most important thing of VTS is to provide enough speed and capacity.

The purpose of this study is to provide a proposed concept that using the Ferris wheel idea on VTS, and to discuss whether it can replace the traditional VTS or not.

\section{VTS THAT RELATE TO FERRIS WHEEL IDEA}

In order to propose a Ferris wheel lift system, we need to take some working principle of existing VTS. There are 2 types of VTS related to the Ferris wheel lift system, Inclined Lift System and Paternoster Lift System.

\section{A. INCLINED LIFT SYSTEM}

"Staircases and later elevators were originally developed to overcome the difficulties of changing levels as comfortably as possible. Inclined railways were popular from the last quarter of the 19th century into the 1930s. Otis built an incline railway in the curved legs of the Eiffel Tower in Paris to carry passengers and freight, installed an inclined catwalk in the Goodyear Zeppelin Plant in Akron, Ohio, in 1930 and built an incline elevator at the Thornhill Golf Course in Toronto in 1933.". Actually, inclined lift is a kind of traction elevator, but unlike the normal one, inclined lift is working on a slope. Most of the components that you find in inclined lift are similar to the vertical traction lift.

The main different of the inclined lift and other traction lift is that the inclined lift not only carry people moving in vertical way, but also horizontal way.

\section{B. PATERNOSTER LIFT SYSTEM}

Paternoster lift is also a kind of traction elevator and it first found in 1866. Dr Lee Gray(2005) state that "the first reference to this new elevator system is found in an 1866 British Patent (Patent No. 1,845, July 13, 1866) granted to a P. Ellis."

He also state that the development of Paternoster lift is step by step. After the patent of P. Ellis, Messrs. Turner and Co. has introduced 'Turner's Continuous Steam Hoist for passengers or goods" in early 1870s; Frederick Hart patented his Endless Chain Lift (Patent No. 81, January 5, 1878) in 1878; R. Waygood \& Co. patent for a paternoster elevator (Patent No. 3824, September 21, 1880) in 1880; follow is a American call Walter Folstead, he patented an design that had "as its object to provide means whereby a series of cars attached to an endless chain or belt may be adapted to carry loads both up and down at the same time" (Patent No. 309,449 , Elevator, December 16, 1884) in 1884. From the above, you can see that idea of paternoster is spread out from Europe to America.

In a typical paternoster lift system, it contains electric motor, guide rails, sheave, etc. The different is that paternoster lift using liftcar to replace the counterweight and 
make the system become continues system. A set of typical paternoster lift using 2 vertical lift shafts and include several liftcar. All liftcars running in same rail and follow one by one. When it is running, the liftcars in 2 lift shafts are continue going up and down and that's why paternoster lift also called Continues Lift.

The most important feature of the paternoster lift is that it can work in continues way. As we know, the traditional traction elevator is served by single lift shaft, when the passengers miss the lift, they need to wait for the liftcar rising and lowing, or the passenger wait for the other. Since the paternoster using 2 lift shafts and each lift shaft just serve single direction liftcar. Therefore, passenger can get in the liftcar in a short waiting period.

\section{TECHNOLOGY INVOLVED}

As I mention above, the principle that the Ferris wheel lift system use is base on the inclined lift system and paternoster lift system. But since the construction method of the propose system is different, new construction method to be developed accordingly.

The proposed Ferris wheel lift system must use the guide rail to provide a stable movement, yet, the connection between the liftcar and the guide rail is not at two side, is at the top, back or the bottom of the liftcar, when the system consider to be built on the façade of the building.

Moreover, the proposed system will be driven by an electric motor and steel cable will be connected to the liftcar. In the traditional paternoster lift system, the steel cable and liftcar are connected one by one, as a result, when one liftcar stop, all the other stop, and this will lower the efficiency of whole system. The method that I introduce in this proposed system is similar with the new paternoster lift system of Hitachi that announced in the $7^{\text {th }}$ China World Elevator Escalator Expo at March, 2006. That method was connecting two liftcars with one steel cable, so that when one liftcar stop, it will just affect the other which connected by same steel cable, but not the others on the cycle.

In fact, the proposed system can built in any form, therefore, the system will fit for the layout, not the layout fit for the system.

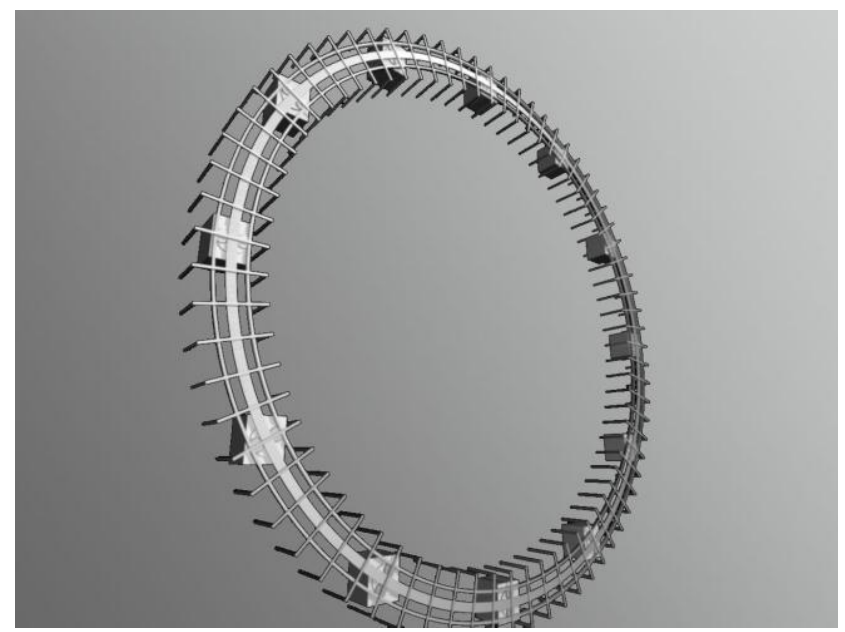

Fig 1. Proposed Ferris Wheel lift system

Finally, as the above is just only a proposal, it did not means that it is the most suitable method to run the system. Actually, the liftcar can drive by itself and install without the steel cable when it have a self driving electric motor, just like a railway system, it can let the whole system more flexible, that means when one of them stop, it will not affect the other. So what technology will use in the system is discussible.

\section{PLACES OF APPLICATION}

The propose system can be installed inside or outside the building, ie, façade. As I emphasize before, this system aims to let architect design more freely. But I would like to point out that calculation of floor area should be concerned when using the system outside the building.

In fact, if the proposed system is install inside the building, the overall area use is still less than traditional VTS, tables below are showing the relation between quantity of liftcar and area of lift shaft.

Table 1. Lift shaft area that traditional lift system use in 10 storey building

\begin{tabular}{|c|c|c|c|}
\hline \multicolumn{4}{|c|}{ Traditional Lift system } \\
\hline $\begin{array}{c}\text { Number(s) of } \\
\text { liftcar }\end{array}$ & $\begin{array}{c}\text { Number(s) of } \\
\text { lift shaft }\end{array}$ & $\begin{array}{c}\text { Total area of lift } \\
\text { shaft(say } \\
10 \mathrm{~m}^{2} / \text { floor) in } \\
10 \text { storey } \\
\text { building }\end{array}$ & $\begin{array}{c}\text { Area use of one } \\
\text { liftcar per } \\
\text { floor }\left(\mathrm{m}^{2}\right)\end{array}$ \\
\hline 1 & 1 & 100 & 10 \\
\hline 2 & 2 & 200 & 10 \\
\hline 3 & 3 & 300 & 10 \\
\hline 4 & 4 & 400 & 10 \\
\hline 5 & 5 & 500 & 10 \\
\hline 6 & 6 & 600 & 10 \\
\hline 7 & 7 & 700 & 10 \\
\hline 8 & 8 & 800 & 10 \\
\hline
\end{tabular}


Table 2. Lift shaft area that proposed Ferris Wheel lift system use in 10 storey building

\begin{tabular}{|c|c|c|c|}
\hline \multicolumn{4}{|c|}{ Proposed Ferris Wheel Lift system } \\
\hline $\begin{array}{c}\text { Number(s) of } \\
\text { liftcar }\end{array}$ & $\begin{array}{c}\text { Number(s) of } \\
\text { lift shaft } \\
\text { Total area of lift } \\
\text { shaft(say } \\
10 \mathrm{~m}^{2} / \text { floor) in } \\
10 \text { storey } \\
\text { building }\end{array}$ & $\begin{array}{c}\text { Area use of one } \\
\text { liftcar per } \\
\left.\text { floor(m }{ }^{2}\right)\end{array}$ \\
\hline 1 & 2 & 200 & 20 \\
\hline 2 & 2 & 200 & 10 \\
\hline 3 & 2 & 200 & 6.7 \\
\hline 4 & 2 & 200 & 5 \\
\hline 5 & 2 & 200 & 3.4 \\
\hline 6 & 2 & 2.9 & 2.5 \\
\hline 7 & 2 & & \\
\hline 8 & 2 & 200 & 4 \\
\hline
\end{tabular}

We can see from the tables, when the number of liftcar increase in the traditional lift system, the total area of lift shaft also increase since one lift shaft serve one liftcar. However, refer to table 2, the lift shaft area still remain in 20 $\mathrm{m}^{2}$ pre floor when the number of liftcar increase, this is because the whole system is just using two lift shaft in each floor (one for up and one for down), that's means the area of lift shaft will not increase when the number of liftcar increase. Therefore the propose system can save a lot of area if it is install inside the building.

\section{CONCLUSION}

When the Ferris wheel concept applies on the VTS, several things that we need to concern.

\section{A. SAFETY}

Safety is a big concern in VTS, especially in paternoster type lift system. Liftcars are non-stop running on a traditional paternoster lift system, it is very danger to the passenger if they cannot get in the car. Therefore, in the propose system, liftcar can stop to let people get in and out. In order not to affect the whole system when the liftcar stops, each liftcars can be self-operated.

\section{B. LOCATION}

Location of the system is another concern. When the proposed system decide to install inside the building at the very beginning of the construction stage, less concern on location. But if not, we should consider the buildings types, construction materials, weather, maintenance method, etc before determine the location.
In this study, I have tried to apply the Ferris wheel idea on the VTS. In the history of VTS, paternoster lift system is the most similar system with the propose system.

Actually, when the propose system continues to develop, you will find that we cannot just take paternoster lift and inclined lift as a reference, other system such as railway and roller coaster are also have a close relationship with the propose system. Therefore, we need to refer to all similar system, and take their advantage to make a safety, and efficiency system.

Moreover, as the proposed system can add on the building façade after the building have finish construction, I think it can really help those having VTS problem (large population flow, shortage of VTS).

On the other hands, if the building have less population flow, the proposed system also can help. When the proposed system add on the façade of the building, it may become an architectural feature of the building and attract people.

Finally, we need to have more study to make the propose system come true, when all problems are solved, it is possible to install the propose system in the building, and I hope this system can help people to enjoy the vertical transportation trip.

\section{REFERENCES}

[1] Arianna Callocchia (2005) "High-tech lifts in London", Elevatori, March/April, pp. 89-91

[2] Elemér Károly Nagy (2006) "Passenger traffic models in lift systems", Elevatori, May/June, pp. 26-32

[3] Giulio Citterio (2006) "A challenge for future lifts", Elevatori, November/December, pp. 56-66

[4] Gray Lee (2006) "TWO CARS IN ONE SHAFT", Elevator World, May, pp. 96-102

[5] John Hurst (2007) "New Technologies Provide Options for Making Escalators More Energy Efficient", Elevator World, January, pp. 7072

[6] Kenji. Inoue et al. (2005) "New traction machine for machine roomless elevators", Elevatori, January/February, pp. 34-42

[7] Stefano Pozzato (2007) "PLC intelligence at the service of lifts", Elevatori, January/February, pp. 62-65 G.C. Barney AND S.M. dos Santos (1985) "Elevator traffic analysis design and control", London : P. Peregrinus

[8] G.C. Barney (1986) "Elevator technology", Chichester: Ellis Horwood

[9] G.C. Barney et al (2001) "Elevator \& escalator micropedia", Sedbergh: GBA

[10] G.C. Barney (2003) "Elevator traffic handbook: theory and practice", London, New York: Spon Press

[11] George R. Strakosch (1983) "Vertical transportation : elevators and escalators", New York: Wiley

[12] George R. Strakosch (1998) "The vertical transportation handbook", New York: Wiley

[13] K.J. Butcher and J. Wilson (1993) "Transportation systems in buildings", London : The Chartered Institution of Building Services Engineers

[14] Lubomir Janovsky (1993) “Elevator mechanical design", New York: Ellis Horwood 
